\title{
UN POEMA TIRADO AL MAR: CONTACTOS POÉTICOS ENTRE CARLOS DRUMMOND DE ANDRADE Y JOSÉ AGUSTÍN GOYTISOLO
}

\author{
Margareth dos Santos
}

\begin{abstract}
RESUMEN
Ese artículo propone una discusión sobre la escritura bajo censura y cómo dos poetas, distantes geográficamente y de dos lenguas distintas, pueden enlazarse por el deseo de esquivar la censura y hacer que su palabra cruce fronteras. En la mano doble de esa difícil tarea, los poetas José Agustín Goytisolo y Carlos Drummond de Andrade, desde la Península Ibérica y Brasil, comunican su deseo de ver extinto el silencio que les sofoca la voz, que les reprime la expresión fluida del verbo poético. A partir del análisis de dos poemas: "Notícias de Espanha", de Drummond, y "Noticias a Carlos Drummond de Andrade", de Goytisolo, señalaremos como se manifiesta en ambos el dolor por el muro de silencio que tapia las casas españolas, centrados en la articulación entre el deseo de contar y la imposibilidad de saber, expresa por dichos versos, discutiremos cómo el contacto poético de Drummond y Goytisolo revela momentos de inflexión en las historias brasileña y española.

Palabras clave: Drummond de Andrade - Carlos, Agustín Goytisolo - José, contactos poéticos, escribir bajo censura, poesía española y brasileña contemporáneas.
\end{abstract}

\begin{abstract}
This paper proposes a discussion on writing under censorship and how two poets, geographically distant and with two different languages, can be linked by the desire to overcome the censorship and make their word cross boundaries. In the course of this difficult task, poets José Agustín Goytisolo and Carlos Drummond de Andrade, from the Iberian Peninsula and Brazil, communicate their desire to extinct the silence that stifles their voice and represses the fluent expression of the poetic verb. From the analysis of two poems: "Notícias de Espanha", of Drummond, and "Noticias a Carlos Drummond de Andrade", of Goytisolo, we intend to indicate how the pain of the wall of silence that block off the Spanish houses is manifested in both, centered the joint between the desire for telling and the impossibility of knowing, which is expressed in these verses, we'll discuss how the poetic contact between Drummond and Goytisolo reveals moments of turning points in Brazilian and Spanish histories.

Key words: Drummond de Andrade - Carlos, Agustín Goytisolo - José, poetic contact, writing under censorship, Spanish and Brazilian contemporary poetry.
\end{abstract}

Dra. Margareth Dos Santos. Profesora en la Cátedra de Literatura Española, Departamento de Letras Modernas, Universidad de São Paulo.

Correo electrónico: marsanto@usp.br

Recepción: 22- 10- 12

Aceptación: 30- 11- 12 


\section{Introducción}

Ese artículo propone una discusión sobre la escritura bajo censura y cómo dos poetas, distantes geográficamente y de dos lenguas distintas, pueden enlazarse por el deseo de esquivar la censura y hacer que su palabra cruce fronteras. En la mano doble de esa difícil tarea, los poetas José Agustín Goytisolo y Carlos Drummond de Andrade, desde la Península Ibérica y desde Brasil, comunican su deseo de ver extinto el silencio que les sofoca la voz, que les reprime la expresión fluida del verbo poético.

Como enfrentamiento a esa asfixia, los poetas se conectan a través de la composición de los poemas "Notícias de Espanha", de Drummond, y "Noticia a Carlos Drummond de Andrade", de Goytisolo. Esos títulos en sí ya nos indican el juego de pregunta y respuesta establecido entre los versos del brasileño y del barcelonés, ambos, en tiempos y espacios distintos, recurren y valoran momentos fundamentales en sus historias y reconocen la palabra oprimida por el yugo de la censura y del totalitarismo.

Para que comprendamos esos momentos y cómo se articula el "contacto poético" de esos escritores, es necesario que empecemos nuestro recorrido ubicando a los poetas en la convergencia de sus historias personales y colectiva. En 1948, Drummond publica en Río de Janeiro su libro Novos poemas, cuando Brasil acababa de pasar por una dictadura, el denominado Estado Novo (1937-45). El país aún se encontraba bajo una censura moribunda, y esa situación posibilitó a Drummond publicar los versos compuestos entre los principios de los años cuarenta. Del otro lado del océano, veinte años después, en 1968, la dictadura franquista, aunque viva, empezaba a dar señales de debilidad. Aprovechándose de ese soplo de aire nuevo, Goytisolo publica Algo sucede (1968), en el cual señala que algo empezaba a suceder como el propio título busca indicar.

A través de los versos de "Notícias de Espanha" y de "Noticias a Carlos Drummond de Andrade" el poeta de Minas Gerais y el poeta barcelonés se comunican entre urgencia y mansedumbre, y la configuración de ese entramado de versos se constituye como elemento central de nuestra discusión, en el cual proponemos leer los poemas como un deseo de dialogar, pues, aunque las poéticas estén distantes en el tiempo y en el espacio, los versos de Drummond y de Goytisolo se hermanan por el dolor por el muro de silencio que tapia las casas españolas, impidiéndoles hablar abiertamente.

A partir de esa propuesta de "posible diálogo poético", pretendemos demostrar cómo verdades soterradas emergen y proyectan su alcance estético y social en las poéticas brasileña y española, revelando la posición del hombre, del intelectual y del poeta en sociedades marcadas por el desencanto y la opresión.

\section{El poema tirado al mar}

Novos poemas (1948) es un libro corto, compuesto por una compilación de doce poemas. Aunque pequeño, su conjunto de versos nos llama la atención por su carácter de obra de transición, pues notamos que éste oscila, a lo largo de sus versos, entre la beligerancia y la melancolía. A causa de esa dinámica pendular, es posible afirmar que el volumen guarda relaciones con el libro anterior de Drummond, A Rosa do povo (1945), en el cual el escritor acaricia con sus versos el sueño social y la posibilidad de comunicarse con el otro por la veta poético social, a la vez que revela un tono desesperanzado ${ }^{1}$.

Es precisamente ese tono el que hace que el volumen de 1948 proyecte conexiones con el libro posterior de Drummond: Claro enigma (1951), cuyas temática y cadencia nos conducen 
a imágenes "vaporosas" y tristes, como si el poeta señalara la desilusión por la pérdida del ideal revolucionario, cantado en A Rosa do povo y entonado oblicuamente en Novos poemas.

Es cierto que ese canto oblicuo y desilusionado ya empezara a configurarse en los apuntes del poeta en 1945 (compilados por crítico Raúl Antelo), a partir de esos apuntes podemos pensar que dichas observaciones de Drummond bien podrían ser simultáneas a la composición de Novos poemas por la proximidad de las fechas de escritura:

\begin{abstract}
¿Soy un animal político o sólo me gustaría serlo? Esos años alimentando lo que me parecía ideas políticas socialistas y ahora que se abre el momento para defenderlas. ¿Estoy preparado? ¿Puedo militar sin filiarme a un partido? [...] Hay una contradicción insoluble entre mis ideas o lo que supongo mis ideas, y tal vez sean sólo utopías consoladoras, y mi inaptitud para el sacrificio del ser particular, crítico y sensible, en beneficio de una verdad general e impersonal, a veces dura o impiedosa. No quiero ser un energúmeno, un sectario, un pasional o un frío domesticado, conducido por palabras de orden. ¿Cómo puedo convencer a otros, si no me convenzo a mí mismo? (Antelo 1984: 188)
\end{abstract}

Incluso años después del lanzamiento de Novos poemas, Drummond sigue señalando en su prosa un desencanto cada vez más agudo. A principios de 1950, cuando colaboraba para el periódico carioca Correio da manhã, con artículos que el propio poeta denominaría como "divagaciones sobre la vida literaria y otras materias", y que posteriormente serían publicados en el libro Passeios da ilha, el escritor minero vuelve a hablar de sus razones y de sus pocas ilusiones en la vida:

\footnotetext{
Este libro, no lo he escrito: ha ido escribiéndose al sabor de los domingos, en el suplemento literario del Correio da manhã. Su ausencia de pretensión es casi insolente. No prueba nada, excepto que seguimos viviendo; pocas ilusiones resisten, pero cabe al hombre descubrir y usar sus razones de vivir. Sus razones, y no las que le sean inculcadas como ejemplares. (Drummond 1988: 1375)
}

En el texto introductorio al libro se puede averiguar la desilusión y la melancolía que estarán presentes en Claro enigma y que ya han sido levemente tocadas en Novos poemas, será entre las "pocas ilusiones resistentes" y las "razones" del poeta que se inscribirá el carácter de libro de transición del volumen de 1948.

Tal idea de transición (el poeta en el "medio del camino") se detecta cuando se observa que Drummond sigue nutriendo el sueño de la poesía como elemento participativo de la vida del hombre. Sin embargo, paralelamente a esa esperanza, se advierte una expresión vacilante, como si empezara a penetrar en el poeta la duda por el alcance del verbo poético. Pasos titubeantes delinean un itinerario en que el yo lírico oscila entre la solidaridad hacia pequeños dramas cotidianos ("Desaparecimento de Luísa Porto"), pasa por dramas de conciencia y de creación poética ("Pequeño misterio policial ou a morte pela gramática", "Jardim", "Canto esponjoso", "Composição", "Estâncias", "O arco" y "O enigma") y alcanza la expresión de dramas individuales y colectivos ("Canção amiga", "Notícias de Espanha”, "A Federico García Lorca" y "Aliança").

En "Notícias de Espanha"2, poema del cual nos ocuparemos, vemos como Drummond lanza al mar un pedido de noticias atormentado:

Notícias de Espanha

Aos navios que regressam

marcados de negra viagem,

aos homens que neles voltam

com cicatrizes no corpo

ou de corpo mutilado,

peço notícias de Espanha.
Noticias de España
A los buques que regresan
marcados por negro viaje,
a los hombres que allí vuelven
con cicatriz en el cuerpo
o de cuerpo mutilado,
pido noticias de España. 


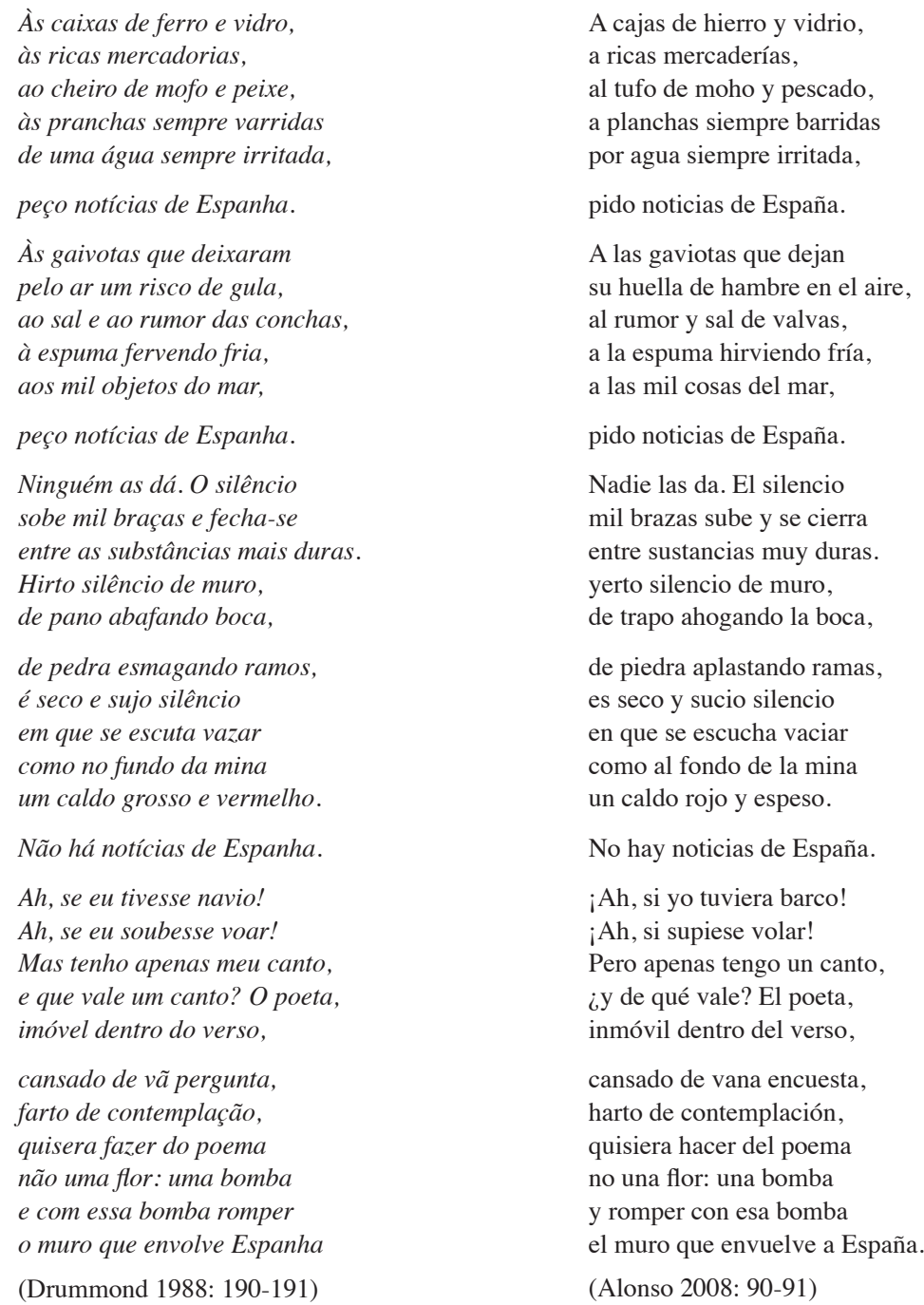

Solidario al drama colectivo, en el poema se evidencian varias inquietudes drummondianas ${ }^{3}$, ésas se concretan en la figura de un sujeto poético escindido entre una búsqueda personal y el esfuerzo estético por situar el papel del arte y del intelectual en la sociedad contemporánea. Confrontado con las exigencias de su tiempo, Drummond expone la precariedad del poeta y el cuestionamiento sobre el alcance del verbo poético en una fina yuxtaposición de imágenes desoladoras.

Al leer el poema, observamos que éste se estructura de manera peculiar a través del género epistolar: por su extensión, se relaciona con la idea de una carta y por su dinámica nerviosa y urgente, se identifica con un telegrama. Por sus imágenes y tono, manifiesta el estado de ánimo de su remitente, a la vez que expresa el deseo por saber algo de su destinatario, sea quien sea el español que recoja "la botella" y lea su mensaje.

El inicio del poema y el momento de su escritura nos indican su posible delimitación temporal: al final de la Segunda Guerra Mundial, cuando muchos españoles creían que los Aliados, vencedores del conflicto, barrerían de España el fascismo. En ese momento, el 
sujeto poético pide noticias de España a los navíos que vuelven, posiblemente desde Europa, marcados por un negro viaje.

A partir de la descripción que se desarrolla en la primera estrofa, se puede inferir el contexto del conflicto mundial, sobre todo por la mención a los hombres de cuerpos mutilados que vienen en estos navíos con sus cicatrices, a ellos se dirige un pedido de noticias indicado en el título.

\author{
Aos navios que regressam \\ marcados de negra viagem, \\ aos homens que neles voltam \\ com cicatrizes no corpo \\ ou de corpo mutilado, \\ peço notícias de Espanha
}

(Drummond 1988: 191)

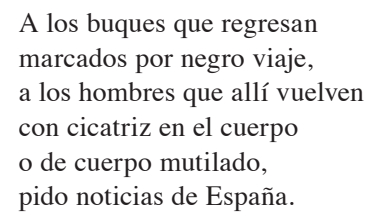

(Alonso 2008: 90-91)

Pautada por una retórica de ruego, casi como una letanía, la indagación se dirige a destinatarios amplios, representantes de los reinos animal y vegetal, del mundo animado e inanimado, dicha gama de destinatarios, por su amplitud inesperada, eleva dramáticamente el tono de desesperación: se piden noticias a las cajas de mercancías, al olor a moho y a pescado.

La irritación del agua se mezcla con diversos olores en un pedido guiado por la sinestesia. A través de una secuencia jadeante de innúmeras y repetitivas solicitudes, el poema va construyéndose a través de un proceso de saturación anafórica, encabezado por la preposición "a" (a las gaviotas, al rumor del hambre, a la espuma hirviendo fría, a las mil cosas del mar), que conduce el esquema repetitivo de los versos. Entre la exasperación y el desaliento, el lenguaje del poema se estructura al borde de la orientación y de la desorientación, entre el deseo urgente y la inutilidad, abriéndose hacia un movimiento que se constituye tanto por repetitivo como por inútil, recordándonos el mito de Sísifo. La secuencia de vocativos, unida a la gama de destinatarios intensifica el tono urgente, contestado solamente por el silencio "ruidoso" que se extiende en distintos niveles y en diferentes lugares.

A ese vivo conjunto de sensaciones, que a su vez nos remite a la idea de movimiento, se interpone el muro de impotencia por la falta de respuesta. El sujeto poético, en su frenesí, se estrella contra la triste constatación de que en España impera el silencio y nadie le concederá la palabra suplicada. Vinculado a esa disposición sinestésica y a la idea de movimiento, se halla el juego de aproximación y alejamiento caracterizado por las tomas rápidas del poema: ora parece que el yo lírico se aproxima a la posibilidad de alcanzar alguna noticia de España, ora parece alejarse definitivamente de la concreción de su anhelo, lo que instituye un discurso mareante a lo largo de sus estrofas.

\author{
Ninguém as dá. O silêncio \\ sobe mil braças e fecha-se \\ entre as substâncias mais duras. \\ Hirto silêncio de muro, \\ de pano abafando boca, \\ de pedra esmagando ramos, \\ é seco e sujo silêncio \\ em que se escuta vazar \\ como no fundo da mina \\ um caldo grosso e vermelho \\ Não há notícias de Espanha
} (Drummond 1988: 191)

\author{
Nadie las da. El silencio \\ sube mil brazas y se cierra \\ entre substancias muy duras. \\ yerto silencio de muro, \\ de trapo ahogando la boca, \\ de piedra aplastando ramas, \\ es seco y sucio silencio \\ en que se escucha vaciar \\ como al fondo de la mina \\ un caldo rojo y espeso. \\ No hay noticias de España. \\ (Alonso 2008: 90-91)
}


Establecida entre el silencio estático y la frenética petición del sujeto poético, la repetición conduce el ritmo del poema, le confiere un poder dinamizador a los versos, impulsando el yo lírico a avanzar en su búsqueda, dilatando cada vez más la amplitud de su pedido de noticias. Todo guiado por la vehemencia de los anafóricos repetidos de manera exhaustiva.

Al conjugar estatismo y movimiento, parálisis e inquietud, el poeta transforma el proceso estilístico de repetición en la representación de una búsqueda personal aliada al esfuerzo estético, resultantes de esa incursión, confluyen en la composición cuestiones ideológicas y estéticas, advirtiéndonos de que el poeta, entre el deseo de lo colectivo y lo individual, opta por elaborar una palabra en que la forma y el tiempo presente estén considerados de manera a reflejar sobre dicha condición estética-ideológica.

En esa confluencia, tras una combinación de imágenes acuáticas y terrestres, táctiles y olfativas, que revindican una noticia, una voz, en medio a ese juego reflexivo, rítmico y visual, aparece por primera vez en el poema la palabra silencio. En el cuarto quinteto, en la mitad del poema, en el medio del camino, un conjunto de piedras impone un muro de silencio.

Se respira un halo asfixiante en el poema, todo abre camino hacia el silencio a través de una cadencia melancólica y exasperada; nos oprimen distintas imposibilidades esparcidas a lo largo del poema: el sonido de las heridas abriéndose en los cuerpos mutilados, el agua irritada, el batir de alas de gaviotas golosas, el rumor de conchas, la espuma hirviendo fría, provocando un chillido hiriente, hasta alcanzar la boca sofocada y la sangre que desliza espesa desde el recio muro. Dolor y silencio conformados por una cadena léxica negativa (silencio, yerto, piedra, dura, seco, sucio, espeso) al cual se suma un conjunto verbal igualmente negativo (cerrar, aplastar, vaciar).

Encerrado en esa conformación sombría, el estribillo de cada quinteto demarca la constancia de la composición agobiante: no hay noticias de España. La repetición, aliada a terribles imágenes, martillan estridentes y rebasan el efecto sonoro de las estrofas, ponen en movimiento la carga lírica del poema en una cadena de sensaciones, pensamiento y sentimiento que se entrelazan a las detenciones, idas y venidas del yo poético y se proyectan una y otra vez contra el muro de silencio español.

Metidos en esa modulación nerviosa, cuando alcanzamos el sexto quinteto, para nuestra sorpresa, la voz parece calmarse y regresar al tono deseante de los tres primeros quintetos, como si se indicara un giro alrededor de sí, como víbora que se muerde la propia cola:

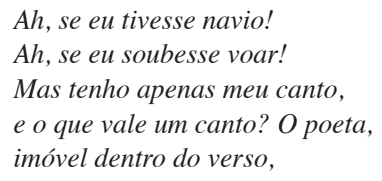

(Drummond 1988: 191)

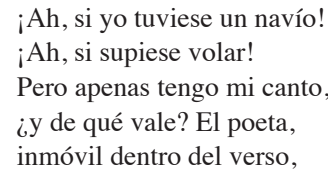

(Alonso 2008: 90-91)

Después de delinear un itinerario constituido por apelaciones exhaustivas, el yo poético se estrella contra el muro de silencio y ahora regresa, a través de la mención al canto, al afán de tocar mansamente la otra punta del océano.

Sin embargo, ese regreso es aparente, pues aunque la sexta estrofa sí inaugure un nuevo ritmo en el poema, quizás más desencantado, acompañado por la melancólica exclamación "ah", lo que se escenifica en sus versos es el enfrentamiento entre el deseo y su concreción, entre el canto y su alcance efectivo. La estrofa explicita un momento de crisis, se indaga por la posición del intelectual en la sociedad contemporánea y qué puede el canto del poeta frente 
a una situación de opresión. Deseos imposibles, conjugados por verbos en imperfecto de subjuntivo, atestan lo que antes apenas se anunciaba: la precariedad del poeta y de su poesía, ambos confrontados a las atroces exigencias de su tiempo. El yo lírico, cercado por innúmeras impotencias (no tiene respuestas, no tiene navío, no sabe volar), percibe que el canto ya no es suficiente y se indaga por su validez.

Como si el verso se transformara en un muro, el poeta se ve encerrado e inmovilizado dentro del poema. El silencio del otro se convierte en el silencio del yo lírico, como si, repentinamente, la palabra poética se hubiera convertido en una forma de inmovilidad (el silencio dentro de las palabras), lo que nos deja perplejos después de tanta furia. En ese momento el poema nos conduce a un final de contornos trágicos:

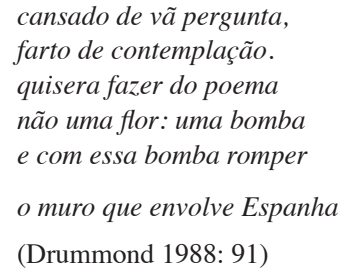

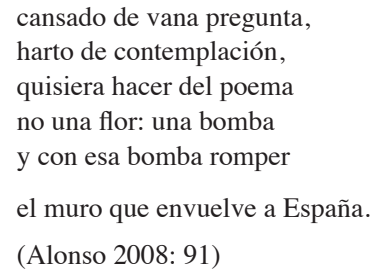

(Alonso 2008: 91)

Tras encerrar la figura del poeta en un muro de palabras, el poema retoma con violencia el contraste entre movilidad e inmovilidad. Cansado de preguntar, harto de tanto contemplar el mar y esperar por una respuesta que se materialice en noticias, se opta por una acción violenta: el poema debe ser más que palabra, debe transformarse en bomba a fin de explotar el muro de silencio que rodea España.

Entre el combate y la desilusión, el poema se desdobla en distintas gradaciones; la yuxtaposición acumulativa en las estrofas van configurando un extenso mosaico de distintos silencios que conforman la opresión en España y en el centro de ese "vasto mundo" se ubica el dibujo de una conciencia crispada y desengañada. En esa disposición, cada grupo de estrofas, como si fueran piezas de ese mosaico, guardan un proceso particular de búsqueda, que va creciendo de forma gradual y fragmentada a la medida que se intensifica el frenesí del sujeto lírico.

Ese sistema de sensaciones urgentes y de imágenes fragmentadas converge hacia un centro común: la indagación sobre el valor de la búsqueda personal y de la propia naturaleza del verbo y tales imprecaciones culminan en una terrible imagen de inmovilidad, final de línea de la agitación en la búsqueda rabiosa por noticias, desagüe en la imagen del poeta estancado en el canto. De ese juego de movilidad/inmovilidad resulta el gusto amargo de la impotencia, de la negación del sueño social y del cuestionamiento de la posición del intelectual frente al totalitarismo. Tristemente, el poema repercute en la voz de las piedras que se escuchan en "O enigma", otro poema del volumen de Novos poemas:

\footnotetext{
Ai! de que serve a inteligência - lastimam-se as pedras. Nós éramos inteligentes; contudo, pensar a ameaça não é removê-la; é criá-la.

Ai! de que serve a sensibilidade - choram as pedras. Nós éramos sensiveis; e o dom de misericórdia se volta contra nós, quando contávamos aplicá-lo a espécies menos favorecidas. (Drummond 1988: 198)
}

¡Ay, de qué sirve la inteligencia!, se lamentan las piedras. Nosotras éramos inteligentes y, a pesar de todo, pensar la amenaza no es salvarla; es crearla.

¡Ay, de qué sirve la sensibilidad!, lloran las piedras. Nosotras éramos sensibles, y el don de misericordia se vuelve contra nosotras cuando contábamos con aplicarlo a especies menos favorecidas. (Crespo 1966: 247) 
Las piedras, que cumplen la función de objeto y de sujeto de esos versos, cuando asumen la voz del poema, se dirigen al lector y le advierten sobre la inutilidad de la inteligencia y de la sensibilidad. Como un eco hiriente, las piedras, gran símbolo de la inmovilidad ${ }^{4}$, parecen proyectar la imagen dolorosa e insoportable que provoca la reacción del sujeto poético en "Notícias de Espanha": se pasa del uso del símbolo de la paz (la flor), al símbolo de la destrucción (la bomba), capaz de explotar el silencio que rodea España. Y todo eso por una palabra que fuera.

\section{Recoger la botella}

Una vez que discutimos el poema de Drummond, pasamos a su articulación con la respuesta de Goytisolo al pedido atormentado del poeta minero. Dicha respuesta se ubica en Algo sucede, el volumen publicado en 1968 se divide en cuatro bloques, en los cuales se abordan, de acuerdo con Luisa Cotoner, en el prólogo a la obra, cuatro grandes cuestiones:

\footnotetext{
la relación del poeta con la poesía, la del poeta consigo mismo y con las personas más cercanas de su entorno familiar o amistoso, la relación del poeta con las mujeres y, por último, la relación del poeta con las circunstancias políticas de su propio país. (Cotoner 1996: 10)
}

"Noticia a Carlos Drummond de Andrade" se ubica en el segundo bloque de la obra, en el cual se entremezclan todos los temas citados, sin que se pueda designarles una rígida división, puesto que se contaminan, se tocan, confundiéndose en sus versos lo público y lo privado, lo personal y lo colectivo, lo íntimo y lo cívico.

Se puede decir que dicha mezcla de temas del conjunto de Algo sucede presenta puntos de contacto con la obra Novos poemas, de Drummond, pues Goytisolo también oscila en su poemario entre la solidaridad hacia pequeños dramas cotidianos ("The publicity" y "Una historia de amor"), pasa por dramas de conciencia y de creación poética ("Aporto nuevos síntomas", "Mis habitaciones", "El poema difícil", "Arma de dos filos", "Piazza Sant'Alessandro, 6") y alcanza la solidaridad con los dramas individuales y colectivos ("Pierre Le Maquis", "Noticia a Carlos Drummond de Andrade", "Algo sucede" y "Nadie está sólo").

Además de esa madeja de dramas que componen la obra, vale la pena llamar la atención para algunas curiosidades del volumen, por ejemplo, el hecho de que el poema que da título al libro fue suprimido por imposición de la censura y sólo se incorporó al conjunto de versos en 1996, mucho después de la muerte del general Franco. La supresión se relaciona a un hecho ocurrido en 1966, la "Capuchinada", que se tradujo en un gran acto de desafío a la dictadura franquista, el acto estaba dirigido a crear un sindicato de estudiantes democráticos:

\footnotetext{
[...] un grupo de delegados de curso de todas las facultades barcelonesas se encerró en el convento de los padres capuchinos de Sarrià. Allí invitaron a varios profesores comprometidos, y junto a treinta y tres personajes de la oposición -artistas e intelectuales "de distinto pelaje", dirá Goytisolo-, redactaron los estatutos del Sindicato Democrático de Estudiantes de Barcelona. Aquel iba a ser el primero constituido abierta y públicamente en España durante la Dictadura. (Dalmau 1999: 468-9)
}

La reunión acaba cuando la policía invade con contundencia el convento y detiene a todos los "no alumnos", pero ya era tarde, la repercusión internacional fue inmediata y la "Capuchinada" pasaría a la historia como un serio problema para el régimen franquista, de ese momento emocionante surgiría no sólo el título del libro de Goytisolo, sino el propio poema título, como homenaje a aquel momento y como símbolo de protesta, solidaridad y esperanza en medio al totalitarismo.

En el poema que nos ocupa también encontramos esa aura de protesta y esperanza, pues en "Noticia a Carlos Drummond de Andrade", el poeta catalán concibe la expresión 
solidaria con el drama político de su país, a la vez que hermana sus inquietudes con las de Drummond. A través de un ejercicio que combina deseos y angustias, Goytisolo estructura sus versos como un acto de captura del sentido de los versos drummondianos, y, simultáneamente, cuestiona el alcance del verbo poético y su posición como escritor sofocado por la opresión.

En la lectura de "Noticia a Carlos Drummond de Andrade", se observa que la manifestación desasosegada del poeta barcelonés también se construye a través del género epistolar, ambos, a través de sus versos y de los títulos de sus poemas, envían noticias. La respuesta de Goytisolo es precisa al pedido plural de Drummond, mientras el poeta minero "lanza su botella" en búsqueda de "noticias", o sea, un plural desesperado y casi indeterminado (cualquier noticia desde el gran silencio español le sirve), el poeta barcelonés determina, en singular, todo el sufrimiento del pueblo español.

En los versos del catalán, la palabra, que tiende al tono coloquial y conversacional, abandonando el decoro formal del género, contesta el ruego del poeta brasileño:

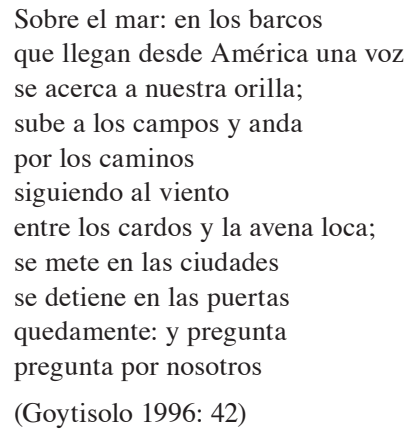

Con el intento de unir visiones y sentimientos ultramarinos, el poema empieza con una puesta en escena: una voz cruza el océano y se acerca a la orilla española, camina por los campos, sigue al viento, se enreda por el paisaje, por las ciudades, hasta detenerse en las puertas. Allí, quedamente, se corporiza el deseo de saber qué pasa en España. Como un juego de espejos, los barcos se multiplican y cargan en su interior una voz indagadora.

La dinámica de esos primeros versos recupera, de manera desconcertante, la poesía de Drummond, el adverbio "quedamente", en el momento del arribo, gana cuerpo y personalidad: es Carlos Drummond quien habla. Se cristaliza, delante de nuestros ojos, el tono y el vocabulario drummondiano, en una cadencia menor e insistente que pregunta repetidamente por aquel silencio peninsular. Como si quisiera realizar el deseo de Drummond de tocar la otra orilla, en la estrofa de Goytisolo, la voz del poeta brasileño llega al oído de los españoles. Lo que se alastra en los versos del catalán, subiendo "mil brazas", no es el silencio, sino la voz que viene desde la orilla brasileña y rebasa el silencio.

En su avance sonoro, la estrofa siguiente sitúa a Drummond en el tiempo y en el espacio $^{5}$, sintetiza el contacto de los escritores españoles con la literatura brasileña, puesto que al poeta minero le oían desde hace tiempo en tierras españolas ${ }^{6}$.

\footnotetext{
Aquí le oímos hace tiempo; hace

ya muchos años olvidados:

quisimos responderle

contarle que ocurría en nuestra casa:

pero el miedo tapiaba los dinteles

cubría las ventanas

para que el gran silencio perdurase
} 


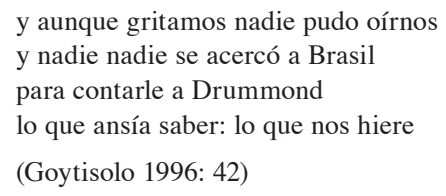

Desde el tono indagador, compuesto por urgencia y mansedumbre, advienen las ganas de haberle contestado antes, pero no era posible, todo estaba tapiado: voces y casas, seres y espacios. La respuesta a gritos nadie pudo oír. Y los años, lejanos y olvidados, emergen a través de la imagen del silencio sofocante.

La repetición del verso (elemento incisivo de esa situación precaria) "y nadie nadie se acercó a Brasil / para contarle a Drummond / lo que ansía saber: lo que nos hiere" (42), se enlaza con las innúmeras insistencias de los versos de "Notícias de Espanha" y alcanza la contundencia de los deseos ultramarinos. Utilizada de manera similar a los versos drummondianos, la repetición en el poema de Goytisolo también rebasa el efecto sonoro, para transformarse en un recurso provocador de sensaciones, uniendo el impulso por saber al deseo de contar, de romper el silencio. En ese "enlace de anhelos negados", la aproximación se ve impedida por lo tapiado.

Sin embargo, incluso en la imposibilidad se producen comprensiones: como en una gradación de saberes, el poeta catalán nos revela que Drummond no solo comprende sino que conoce la marca del dolor.

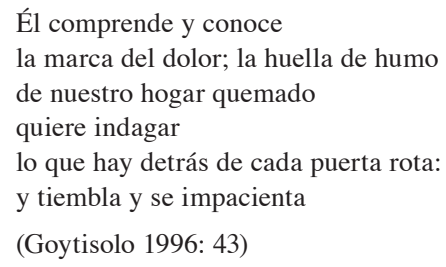

En una disposición modulada por censuras que se combinan en distintos silencios, en distintos tiempos y espacios, la voz de Drummond indaga desde el interior de los versos goytisolianos e, impaciente, tiembla, quiere saber lo que pasa detrás de cada hogar quemado, de cada puerta española cerrada.

El verbo "temblar" captura el movimiento frenético de los versos de "Notícias de Espanha”, la impaciencia y la urgencia de su sujeto poético. Y aunque, veinte años después, Goytisolo constate que la Historia no ha cedido, que la dictadura franquista sigue oprimiendo a los españoles, el deseo y la acción de todos, de poetas y lectores, pueden alzar su voz hacia el cielo y el mar, pueden levantarse por encima de los estandartes y del coro abyecto.

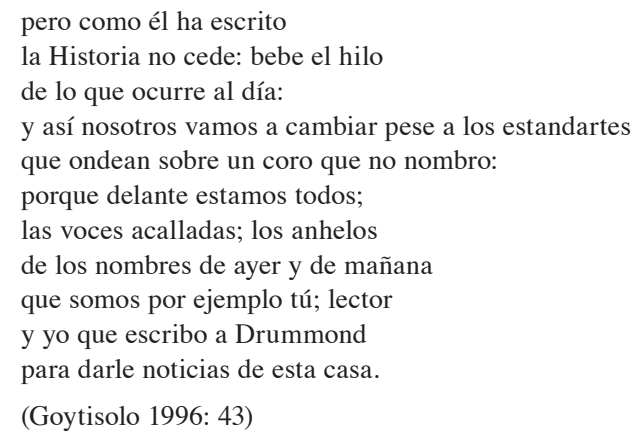


Se constata que los años olvidados no han pasado en vano, la palabra de Drummond había tocado la otra orilla y había conformado un diálogo entablado de manera simbiótica: la pregunta drummondiana fue capaz de nutrir la respuesta de Goytisolo, la desesperación a las palabras de esperanza, el silencio a la voz.

En esa asociación de deseos, los versos de Goytisolo abandonan las tomas rápidas y nerviosas de Drummond, congelan la mirada inestable y fragmentada del poeta minero y privilegian las tomas amplias y acumulativas con versos más largos, caracterizados por una cadencia más lenta, más reflexiva y ponderada de la respuesta goytisoliana.

En el vértigo de esa combinación de preguntas y respuestas, uno se da cuenta de que ese contacto de voces y deseos postula grandes cuestiones humanas: no se trata solamente de dictaduras que se deben superar, de silencios que se quieren transponer, sino del deseo de preguntarse (y quién sabe contestar) por su lugar en el mundo, por su posición frente a los hechos, frente a la vida y a la historia.

Así, metidos en ese amalgama de anhelos ultramarinos, expuestos a tantas angustias y a la constatación de que los días transcurren en silencio, los versos goytisolianos se muestran algo esperanzados, pues, en "Noticia a Carlos Drummond de Andrade", se cree que algo sucede, se cree que por encima de las voces acalladas los deseos de los hombres brasileños y españoles, de ayer y de hoy, se hermanan para enviar noticias el uno al otro, "el intelectual enfrentado al toro de la censura", delante de la impotencia puede decir algo, aunque sus palabras vengan empalagadas por el gusto amargo de la desilusión y de la opresión.

\section{Notas}

1. A finales de los años cuarentas y principios de los cincuentas, Drummond sufrirá con constantes ataques de lo que se convertiría más tarde en las denominadas patrullas ideológicas del Partido Comunista Brasileño (PCB), que exigían de los intelectuales de aquel momento un compromiso no sólo ético sino poético, a veces, casi panfletario. En el caso de Drummond, los ataques se debieron, en parte, porque el poeta aceptó un puesto en el Ministerio de Educación durante el Estado Novo. Y pese al fuerte sentimiento de culpa que el escritor nutría por haberlo aceptado, él no se sometió a esa "dictadura de la palabra", sin embargo, esos embates provocaron algunas decepciones y su consecuente alejamiento de la poesía social.

2. La traducción presentada del poema original se encuentra en la obra Alonso, Rodolfo (Selecc. y Trad.). 2008. 50 poemas escogidos. Carlos Drummond de Andrade. Caracas: El perro y la rana. 90-91. Pero es necesario decir que nuestra lectura parte del poema original de Drummond, por lo tanto, se trata sencillamente de una acción que ofrece una lectura bilingüe.

3. Esa noción de inquietud en la obra de Drummond se encuentra ampliamente discutida por Antonio Candido en su artículo del 2004 "Inquietudes na poesia de Drummond”. En: Vários escritos. São Paulo: Duas Cidades/Ouro sobre azul. 67-98.

4. Vagner Camilo presenta un excelente análisis sobre los símbolos de inmovilidad en la poesía de Drummond en el capítulo "Da comunicação precária ao silêncio das pedras: Novos poemas (1948)" en su obra del 2001, Drummond. Da Rosa do povo à Rosa das trevas. São Paulo: Ateliê. 99-148.

5. Para más información sobre las traducciones de Drummond para el español y su reconocimiento como gran poeta por escritores españoles, consultar su correspondencia con João Cabral de Melo Neto en Süssekind, Flora (Org). 2001. Correspondência de Cabral com Bandeira e Drummond. Rio de Janeiro, Nova Fronteira: Casa de Rui Barbosa.

6. Seguramente, la estrofa confirma el contacto de Goytisolo con la poesía de Drummond a través de las publicaciones de la Revista de Cultura Brasileña y del volumen Poemas, publicado por Rafael Santos Torroella en 1951. La publicación está avalada por João Cabral de Melo Neto, poeta brasileño, embajador de Brasil en los años 40 y 50 en España y amigo de Drummond: "Esta carta será reexpedida 
a ti por mi amigo Rafael Santos Torroella, de Barcelona. A Santos, que admira tu poesía, se le ocurrió proponer a una editorial de Madrid, seguramente la de mejor gusto literario de España, una selección de tu obra, traducida al castellano. Las traducciones ya están listas y la editorial ansiosa para publicarlas. Le falta solamente la autorización del autor. Eso es lo que te pido. Creo que debes enviarla. La editorial es, políticamente, la más limpia. El traductor es aún más limpio que la editorial” (Traducción mía). No cabe duda de que el hecho de que João Cabral de Melo Neto haya mencionado la posición política de Torroella, "de lo más limpia", le habrá convencido a Drummond que estuviera de acuerdo con la publicación, puesto que en esos años España aún seguía bajo la dictadura franquista y los comentarios de João Cabral, amigo y militante político también, le habrían tranquilizado. Tampoco podemos olvidarnos del estrecho vínculo político y de amistad de Torroella y Goytisolo por esos mismos años, como se puede comprobar por los testimonios compilados por Miguel Dalmau en su libro de 1999, Los Goytisolo. Barcelona: Anagrama (ver pág. 317).

\section{Bibliografía}

Alonso, Rodolfo (Selecc. y Trad.). 2008. 50 poemas escogidos. Carlos Drummond de Andrade. Caracas: El perro y la rana. 90-91.

Antelo, Raul. 1984. Literatura. São Paulo: Ática.

Camilo, Vagner. 2001. Drummond: da rosa do povo à rosa das trevas. São Paulo: Ateliê.

Crespo, Angel. 1966. "Muestrario del poema en prosa brasileño. Carlos Drummond de Andrade". Revista de cultura brasileña. 18: 246-247.

1968. "Algunos poemas de Carlos Drummond de Andrade". Revista de cultura brasileña. 27: 379-392.

Crespo, Angel y Damaso Alonso. 1968. "Poemas de Carlos Drummond de Andrade". Revista de cultura brasileña. 3: 165-184.

Dalmau, Miguel. 1999. Los Goytisolo. Barcelona: Anagrama.

Drummond de Andrade, Carlos. 1988. Novos poemas in Poesia e prosa. Rio de Janeiro: Nova Aguilar. 185-198.

Goytisolo, José Agustín. 1996. Algo sucede. Barcelona: Lúmen.

Süssekind, Flora (Org). 2001. Correspondência de Cabral com Bandeira e Drummond. Rio de Janeiro, Nova Fronteira: Casa de Rui Barbosa. 